\title{
Agricultural land use patterns of native ungulates in south- eastern Montana
}

\author{
JAMIE P. SELTING AND LYNN R. IRBY
}

\begin{abstract}
Authors are soil conservationist, Natural Resource Conservation Service, Havre, Mont. 59501; and professor of Wildlife Management, Biology Department, Montana State University, Bozeman, Mont. 59717. At the time of the research, the senior author was a graduate research assistant in the Biology Department, Montana State University, Bozeman, Mont. 59717.
\end{abstract}

\section{Abstract}

Mule deer (Odocoileus hemionus), white-tailed deer (Odocoileus virginianus), and pronghorn antelope (Antilocapra americana) use of 6 agricultural land use categories in southeastern Montana were monitored to identify use patterns at specific sites. Alfalfa (Medicago sativa L.), bottom rangeland, Conservation Reserve Program (CRP) lands, upland rangeland, wheat (Triticum aestivum L.) stubble, and growing wheat were observed during dawn, day, dusk, and night hours over a period of 12 months. Mule deer densities on alfalfa peaked in fall and again in spring. The CRP lands were selected in all seasons. Rangeland sites were most heavily used in winter and summer. White-tailed deer used CRP lands in all seasons except fall. Alfalfa was selected in fall, spring, and summer. Antelope densities on alfalfa were highest in spring and fall, while growing wheat fields were used most in spring. Antelope in the northern study area selected CRP land in all seasons except fall. Densities of animals and patterns of use observed during this study would be unlikely to produce significant impacts on forage or crops at most of our study sites.

Key Words: mule deer, white-tailed deer, pronghorn antelope, habitat use, agriculture

Increasing wildlife populations and demands for greater efficiency in agricultural production have produced conflicts between agricultural and wildlife advocates in the Great Plains (Severson 1981). Both groups perceive damage from wildlife as a problem, but they disagree on its extent and importance (Conover and Decker 1991, Adkins 1991, Lacey et al. 1993, Conover 1994, Wywialowski 1994, Irby et al. 1996). Attempts to measure damage from wild ungulates have been unsatisfactory because of variability in methodology, sampling intensity, and distribution of ungulates at local and regional scales (Tebaldi 1982, Adkins 1991, Matschke et al. 1984).

This study was initiated to provide quantitative information on wild ungulate use of agricultural lands in southeastern Montana.

Research was funded by the USDA through Sustainable Agriculture Research and Education Grant LW-91-24 directed by Drs. J. Riesselman and J. Johnson. Authors wish to thank E. Williams, Dr. B. Thompson, Dr. D. Gustafson, Dr. J. Lacey, Dr. C. Wambolt, and members of the Carter-Fallon Forage Committee for assistance during the project and landowners in Carter County who allowed us access to their property.

Manuscript accepted 21 Sep. 1996
Resúmen

Los usos por parte del venado burro (Odocoileus hemionus), el venado cola blanca (Odocoileus virginianus) y el antilope pronghorn (Antilocapra americana) de seis categorías de tierras de uso agrícola en el sureste del estado de Montana se examinaron para identificar las tendencias de uso en sitios específicos. Observamos la alfalfa, los terrenos de pasto bajos, las tierras del Programa de Reserva para la Conservación (el CRP), los terrenos de pasto altos, el rastrojo de trigo, y el trigo creciente durante el alba, el día, el crepúsculo y la noche a través de un período de doce meses. Las densidades del venado burro en la alfalfa alcanzaron el máximo en el otoño y otra vez en la primavera. Estos venados seleccionaron las tierras del CRP en todas las estaciones. Utilizaron los sitios de los terrenos de pasto más durante el invierno y el verano. Los venados cola blanca usaron las tierras del CRP en todas las estaciones menos el otoño. Seleccionaron la alfalfa en el otoño, la primavera y el verano. Las densidades del antílope en la alfalfa alcanzaron el máximo en la primavera y en el otoño, mientras se utilizaron los sembrados de trigo creciente más durante la primavera. Los antilopes en el área norteña del estudio seleccionaron las tierras del CRP en todas las estaciones menos el otoño. Es improbable que las densidades de los animales y las tendencias de uso observadas durante este estudio produzcan impactos substanciales en los pastos o en las cosechas de la mayor parte de nuestros sitios estudiados.

Ranchers in Carter and Fallon Counties identified consumption of locally grown hay and forage from native range by wild ungulates as a possible economic threat. Studies sponsored by the Montana Department of Fish, Wildlife, and Parks (MDFWP) in the area (Egan 1957, Campbell 1970, Freeman 1971, Griffiths 1990 , Olenicki 1993) did not support this contention, but they focused on the ecology of deer and antelope with agricultural impacts addressed as a secondary objective. This study was designed to focus on animal use patterns in agricultural cover types. The primary objectives were to 1 ) identify seasonal preferences of wild ungulates for agricultural cover types, and 2) to determine if topographic, physical, and biological characteristics associated with specific sites could be used to predict the abundance of wild ungulates at specific sites. 


\section{Materials and Methods}

\section{Study Area}

The study was conducted on sites selected along 2 routes in Carter County, Montana. Observation sites where animals were counted ranged in size from 10 to 100 ha. Sites were placed along unpaved county roads that were maintained as school bus routes to insure year-round accessibility. The northern route (Ekalaka route) included 42 observation sites that encompassed an area of 1,213 ha. Roads on this route encircled the Ekalaka Hills division of Custer National Forest but were located in open, rolling prairie at distances of 0.5 to $6.4 \mathrm{~km}$ from forested areas. Vegetation in prairie areas consisted of sagebrush-grassland communities interspersed with agricultural lands. Dominant species were big sagebrush (Artemesia tridentata Nutt.), crested wheatgrass (Agropyron desertorum (Fisch.) Schultes), western wheatgrass (Agropyrum smithii (Rydb.) Gould), prairie junegrass (Koeleria macrantha (Ledeb.)Shultes), blue grama (Bouteloua gracilis (H.B.K.) Lag. ex Stud.), and needle-and-thread (Stipa comata Trin. and Rupr.). The CRP lands contained crested wheatgrass and alfalfa (Medicago sativa L.). Important tree and shrub species along streams and coulees were green ash (Fraxinus pennsylvanica Marsh.), common snowberry (Symphoricarpos albus (L.) Blake), fragrant sumac (Rhus aromatica Ait.), and common chokecherry (Prunus virginiana L.).

The southern route (Box Elder route) included 14 observation sites totaling 462 ha located along a $21-\mathrm{km}$ reach of Box Elder Creek. This route was characterized by rolling plains dissected by ephemeral creeks. Box Elder Creek frequently is dry during summer but had surface water throughout our study. Dominant species in the area were similar to those on the Ekalaka route except for stands of box elder (Acer negundo L.), plains cottonwood (Populus deltoides Bartr. ex Marsh.), and silver buffaloberry (Shepherdia argentea (Pursh) Nutt.) along portions of Box Elder Creek and greasewood (Sarcobatus vermiculatus (Hook.) Torrey) communities in some bottom land sites.

Average annual precipitation in the Ekalaka area $(39.2 \mathrm{~cm})$ is slightly greater than in the Box Elder area $(32.9 \mathrm{~cm}$ ) (NOAA 1993). Seventy-five percent of precipitation in both areas occurs as rain during April-September (Carter County Conservation District 1976). Precipitation for September 1992 to August 1993 was above average for both study areas with significantly higher rainfall occurring in June and July (NOAA 1993). Long term average temperature is $20^{\circ} \mathrm{C}$ for July and $7^{\circ} \mathrm{C}$ for January.

At the time of the study, Carter County was approximately $90 \%$ rangeland, $1.7 \%$ crops, $1.9 \% \mathrm{CRP}, 4.2 \%$ forest, and $2.2 \%$ other. Major agricultural crops, in order of abundance, were winter wheat (Triticum aestivum L.) (including fallow), alfalfa, barley (Hordeum vulgare L.), oats (Avena sativa L.), rye (Secale cereale L.), and safflower (Cartthamnus tinctorius L.). Sixty-five percent of the land is deeded, $7 \%$ is state land, and the remainder is federally owned. (U.S.D.A., Agricultural Stabilization and Conservation Service, unpubl. data).

Deer and antelope harvest reports (Montana Dep. Fish, Wildlife and Parks, unpubl. data) for 1992 suggested that mule deer populations were at or slightly above the 30 -year average. Whitetailed deer harvest levels were approximately average, and antelope harvest was slightly above average.

\section{Ungulate Count Procedure}

From September 1992 to August 1993, deer and antelope counts were conducted on 56 sites located within 6 major land use categories. These were alfalfa, bottom rangeland, Conservation Reserve Program lands (CRP), upland rangeland, wheat stubble, and growing wheat (Table 1). Seven to 10 observation sites were chosen in each land use category. Travel routes were designed so the direction of travel could be alternated.

At each observation site, presence of livestock, number and species of deer, and number of antelope were recorded $(1$ deer or 1 antelope = 1 observation). Activity and age were recorded when possible.

Table 1. Land use categories used in wild ungulate surveys. Numbers of sites (n) and number of hectares (ha) for each type are given in the table.

\begin{tabular}{|c|c|}
\hline Land Use Type & Characteristics \\
\hline $\begin{array}{l}\text { Alfalfa } \\
(\mathrm{n}=10, \mathrm{ha}=235)\end{array}$ & $\begin{array}{l}\text { Fields with a grass-alfalfa mix containing at least } \\
20 \% \text { alfalfa canopy coverage prior to first harvest. } \\
\text { Harvested for livestock feed (not seed production). }\end{array}$ \\
\hline $\begin{array}{l}\text { Bottom Rangeland } \\
(\mathrm{n}=10, \mathrm{ha}=348)\end{array}$ & $\begin{array}{l}\text { Native or reseeded rangeland used for livestock } \\
\text { grazing in any season. Located in the lowest ele- } \\
\text { vation in relation to surrounding topography. } \\
\text { Usually adjacent to perennial or intermittent creeks. }\end{array}$ \\
\hline Conservation Reserve & Lands enrolled in the Conservation Reserve Program. \\
\hline $\begin{array}{l}\text { Program (CPR) } \\
(\mathrm{n}=10, \mathrm{ha}=351)\end{array}$ & $\begin{array}{l}\text { Seedings older then three years containing an aver- } \\
\text { agemix of alfalfa ( } 0.45 \mathrm{~kg} \text { pls (pure live seeds)) and } \\
\text { crested wheatgrass ( } 1.8 \mathrm{~kg} \text { pls). Pubescent } \\
\text { (Agropyron trichophorum (Link) Richt.) and inter- } \\
\text { mediate (A. intermedium (Host) Beauv. wheatgrass } \\
\text { were often substituted and yellow sweet clover } \\
\text { (Melilotus officinalis (L.)) was included occasionally. }\end{array}$ \\
\hline
\end{tabular}

Upland Rangeland Native or reseeded rangeland used principally for $(\mathrm{n}=10, \mathrm{ha}=319)$ livestock grazing in any season. Low relief sites located in high elevations in relation to surrounding topography. Usually elevated 2 or more terrace levels above bottom rangeland sites.

Wheat stubble Winter wheat that was seeded in the fall of 1991 and ( $n=9$, ha $=231$ ) harvested in the early fall of 1992. Plants were mature when the study was initiated

Growing wheat $(\mathrm{n}=7, \mathrm{ha}=183)$

Winter wheat that was seeded in the fall of 1992 to be harvested in the early fall of 1993 . Winter wheat that was planted and matured during the study period.

Counts were conducted on each observation site at 4 time periods: 1) dawn ( $1 / 2$ hour before to $1 / 2$ hour after sunrise); 2 ) day ( 2 hours after sunrise to 2 hours before sunset); 3 ) dusk (15 minutes before sundown to 45 minutes after sundown); and 4) night (1 hour after sundown until the observation route was complete). Observations were not conducted when fog, snow, or rain impaired visibility. Binoculars were employed to verify species sighted at dawn, day, and dusk. Night observations were aided by a 1.5-million candle power spotlight and binoculars.

To assess observation efficiency, 1 person walked through a set of observation sites after making counts from the road while another observer watched for animals that flushed. The CRP lands were tested in winter and summer. Alfalfa, bottom rangeland, and upland rangeland were tested only in summer.

Seasons were defined as fall (September-November), winter (December-February), spring (March-May), and summer (June-August). Counts were conducted 10 times per season at 
each time period giving 40 counts at each observation site per season.

To compensate for unequal observation site sizes, an average ungulate density was determined for each land use category in each month. Monthly data were combined to form seasonal estimates.

The total number of deer and antelope observed in each land use category in each season was compared to availability of land use categories on survey routes (Neu et al. 1974). Results are reported as use less than $(-)$, greater than $(+)$, or equal to $(=)$ availability among all land use categories examined at $P<0.05$.

\section{Wild Ungulate Associations with Landscape Variables}

For all observation sites, distance to the nearest agricultural crop (alfalfa, CRP, and wheat) was measured from topographic maps. Slope and the distance from each observation site to the nearest perennial creek, intermittent creek, hiding cover, forest, and occupied homestead were also measured. Data from both study routes were combined to test for associations between landscape variables and deer and antelope abundance. Seasonal correlations and comparisons were determined by Spearman rank correlations (Rs) and Kruskal-Wallis tests (Conover 1980). We determined if combinations of landscape level variables were useful in predicting ungulates numbers at specific sites using multiple linear regression (Neter et al. 1993). Individual models were developed for each species in each season. Ungulate density (total number of ungulates observed on a site in 40 replicated counts/area of the site) was the dependent variable in all models. The independent variables used in the regression models were distances to landscape features and percent slope.

Wild Ungulate Associations with Vegetation and Livestock

Vegetative composition was estimated for alfalfa, rangeland, and CRP at each observation site in late June and early July. Vegetative cover was estimated by recording the percent of the ground covered by grasses, forbs, shrubs, and mosses within 20 by $50 \mathrm{~cm}$ plots at 20 random points at each observation site. The vegetative cover classes were: $<1 \%, 1-5 \%,>5-25 \%,>25-50 \%$, $>50-75 \%,>75-95 \%$, and $>95 \%$. The mid points of the coverage classes were used to calculate means and Spearman rank (Rs) correlations were used to test for associations between wild ungulates and vegetative characteristics for alfalfa, CRP, upland rangeland and bottom rangeland. Spearman rank correlations were also used to test the strength of association between wild ungulates and livestock numbers at observation sites.

\section{Results}

During the study period, 4,687 mule deer, 1,322 white-tailed deer, and 2,767 antelope observations were recorded. Forty-two percent of mule deer, $93 \%$ of white-tailed deer, and $66 \%$ of antelope observations were made on the Ekalaka route. The dominant observed activity in all seasons was feeding, followed by bedding and traveling.

We did not find major differences in sightability among land use categories. In CRP lands, we observed an average of $85 \%$ $(n=10$ tests) of all animals present at night and $80 \%$ ( $n=13$ tests) of all animals present during the day. All other land use cate- gories had less hiding cover available to animals and were checked only during the day ( $n=28$ tests). More than $90 \%$ of the animals present in these types were visible from the road. For all 3 species, the number of observations in land use categories was not proportional to availability of categories in any season (chisquare range $=19.11-3652.83, P<0.05)($ Table 2$)$.

\section{Use Patterns of Agricultural Cover Categories}

Mule deer. Mule deer densities per land use category in individual months varied from 0.0 to $0.42 /$ ha (Fig. 1). In fall, CRP and alfalfa were selected (use>availability) in sites along both observation routes, and all other types were avoided (use<availability) (Table 2). During winter, CRP was selected on the Ekalaka route and upland range on the Box Elder route. Most other categories were used less than expected. In spring and sum-
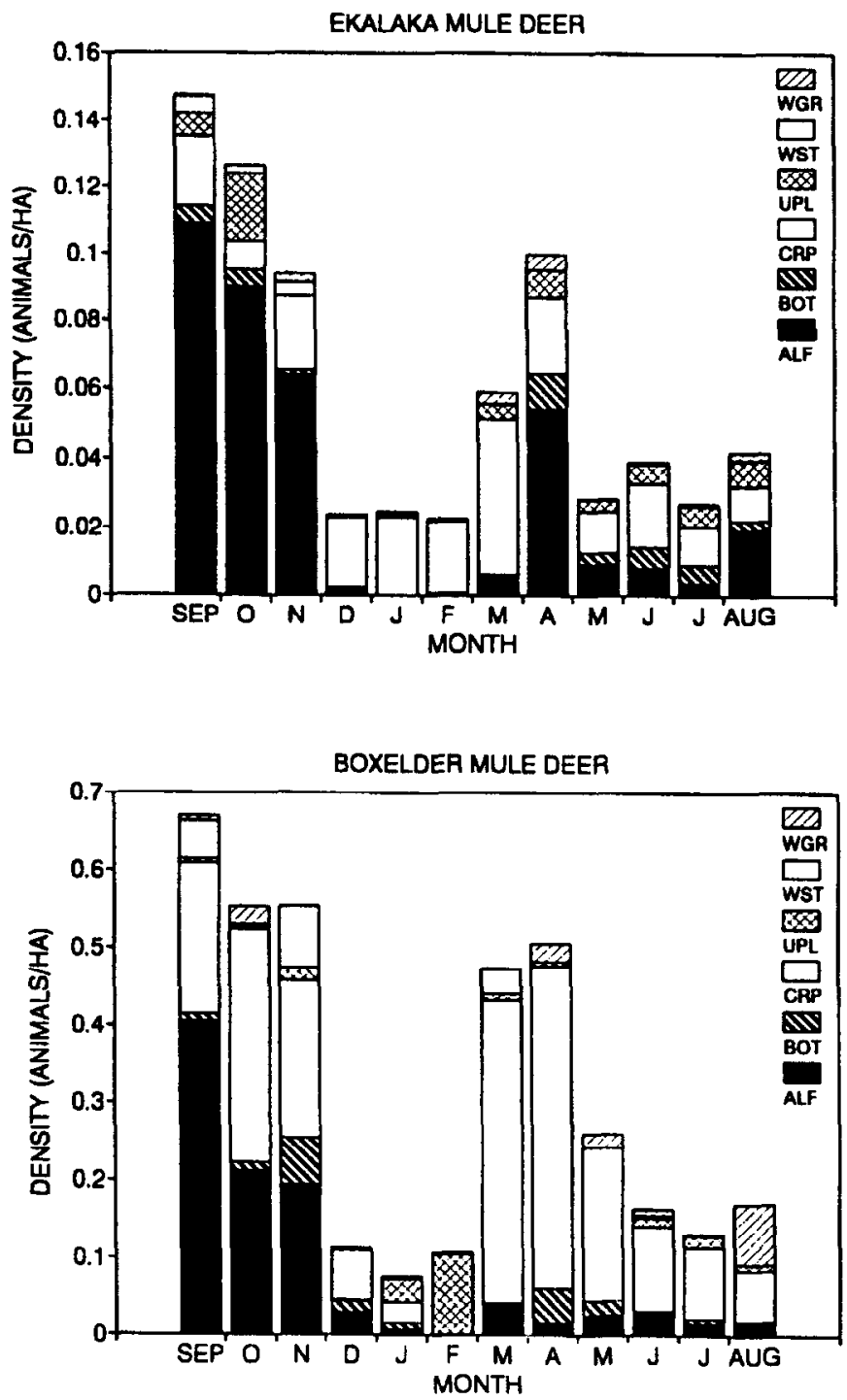

Fig. 1. Average mule deer densities on alfalfa (ALF), bottom rangeland and (BOT), Conservation Reserve Program (CRP), upland rangeland (UPI), wheat stubble (WST), and growing wheat (WGR) observation sites in the Ekalaka and Box Elder study areas from September 1992 to August 1993. 
Table 2. Mule deer, white-tailed deer, and antelope use of agricultural land use categories in the Ekalaka and Box Elder study areas.

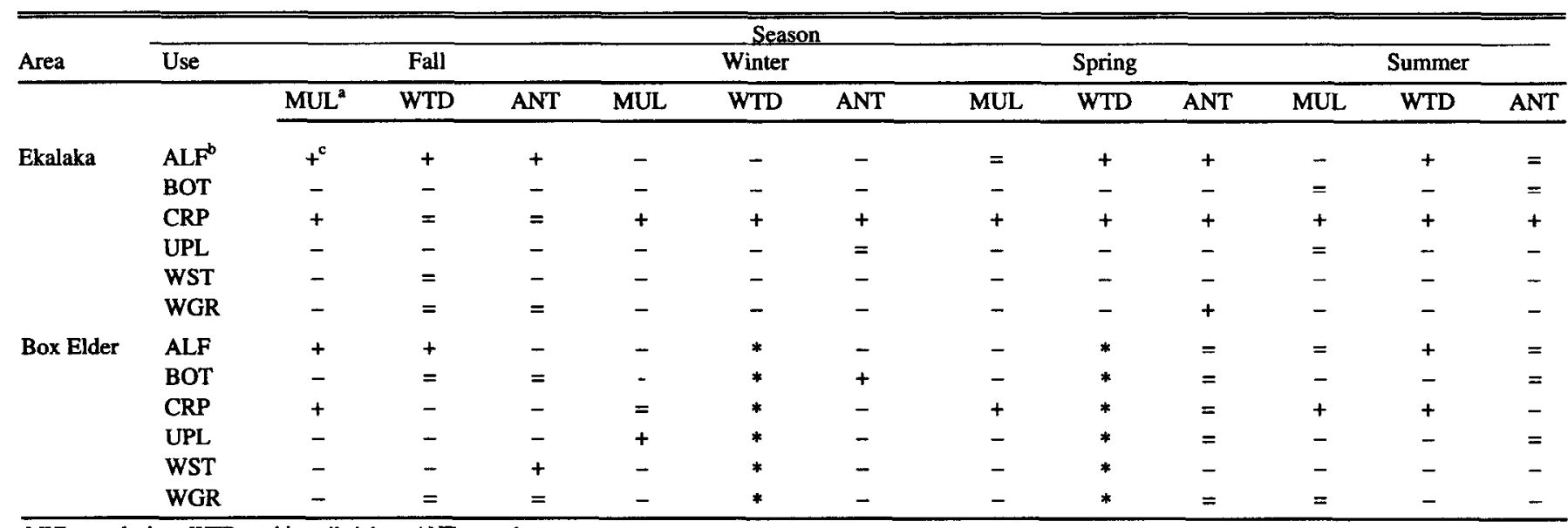

"MUL = mule deer, WTD = white-tailed deer; ANT = antelope.

ALF = alfalfa; BOT = bottom rangeland; CRP = conservation reserve program; $U P L=$ upland rangeland; WST =wheat stubble; $W G R$ $=$ growing wheat.

$(+)=$ use greater than availability; $(=)=$ use proportional to availability; $(-)=$ use less than availability; $(*)=$ no test.

mer, CRP was selected along both routes, and most other categories were avoided.

White-tailed deer. White-tailed deer densities ranged from 0.0 to 0.11 /ha (Fig. 2). In fall, white-tails selected alfalfa and avoided upland range sites. Use of other types was either proportionate to availability or less than availability, but relationships differed between routes (Table 2). In winter, they selected CRP and avoided all other land use categories. In spring and summer they selected alfalfa fields and CRP and used all other land use categories proportionally less than their availability. During winter and spring, very few white-tailed deer were seen on the Box Elder route so selectivity was based only on sites along the Ekalaka route.

Antelope. Monthly antelope density in land use categories varied from 0.0 to $0.58 /$ ha (Fig. 3). Use patterns along the 2 study routes varied more for antelope than for deer (Table 2). In fall, antelope observed on the Ekalaka route selected alfalfa and avoided wheat stubble. On the Box Elder route, they avoided alfalfa and selected stubble. In winter, antelope observed on the Ekalaka route selected CRP and avoided bottom rangeland. The only antelope seen on the Box Elder route in winter were in bottom rangeland. In spring, antelope on the Ekalaka route selected alfalfa, CRP, and growing wheat and avoided other categories. All categories except wheat stubble were used in proportion to availability along the Box Elder route. In summer most categories were used in a similar manner on both routes except CRP. This catcgory was selected in the Ekalaka area and avoided in the Box Elder area.

\section{Wild Ungulate Associations with Landscape Variables}

Mule Deer. Mean numbers of mule deer on the 56 observation sites in each season were negatively correlated with distances to landscape variables in 24 of 36 Spearman Rank Correlations we calculated (Table 3 ), but only 3 correlations were significant $(P<0.05)$. In winter and spring, deer numbers were negatively associated with distance to CRP. In summer, deer numbers were positively correlated with distance to forest cover.
White-tailed Deer. White-tailed deer observations were negatively correlated with landscape variables in 20 of 36 tests (Table 3 ). Four correlations were significant. In fall and spring, more white-tailed deer were seen in sites with little or no slope than in steeper terrain. In spring, white-tailed deer numbers were negatively correlated with distance to CRP and forest cover.

Antelope. Negative associations between antelope numbers and landscape variables were calculated for only 8 of 36 tests. There were significant positive associations between antelope numbers and 2 variables, distance to forest cover and occupied homesteads, in spring and summer.

\section{Multiple Regression Models}

Twelve multiple regression models, 3 species in 4 seasons, were tested. Only 2 of the 12 models detected marginally significant relationships $(P<0.10)$ between wild ungulates and landscape variables. None of the models explained a substantial amount of the variability $\left(R^{2}<0.51\right)$ in ungulate observations (Table 4).

\section{Wild Ungulate Associations with Vegetation Coverage and Livestock}

The average canopy coverage in bottom rangeland sites was $55 \%$ grass, $33 \%$ forb, and $8 \%$ shrub. Canopy coverage for upland sites averaged $49 \%$ grass, $28 \%$ forb, and $11 \%$ shrub. Alfalfa canopy cover prior to the first cutting was $29 \%$. Canopy coverage of the introduced wheatgrasses used in seeding CRP averaged 43\% and alfalfa averaged $6 \%$ (for all CRP fields). Other grasses, other forbs, and shrubs combined had a mean canopy coverage of $7 \%$. Of 12 Spearman correlations calculated ( 3 ungulates species in 4 seasons) for sites with perennial vegetative cover, only 1 was significant $(P<0.05)$. Antelope numbers were negatively associated $\left(R_{s}=-0.803, P<0.01\right)$ with alfalfa canopy coverage in summer.

Livestock distribution varied seasonally in the study area. Cattle were grazed on upland and lowland range sites through the year. In winter, there was a tendency for higher use of bottom rangeland to facilitate feeding operations. In summer, cattle tend- 

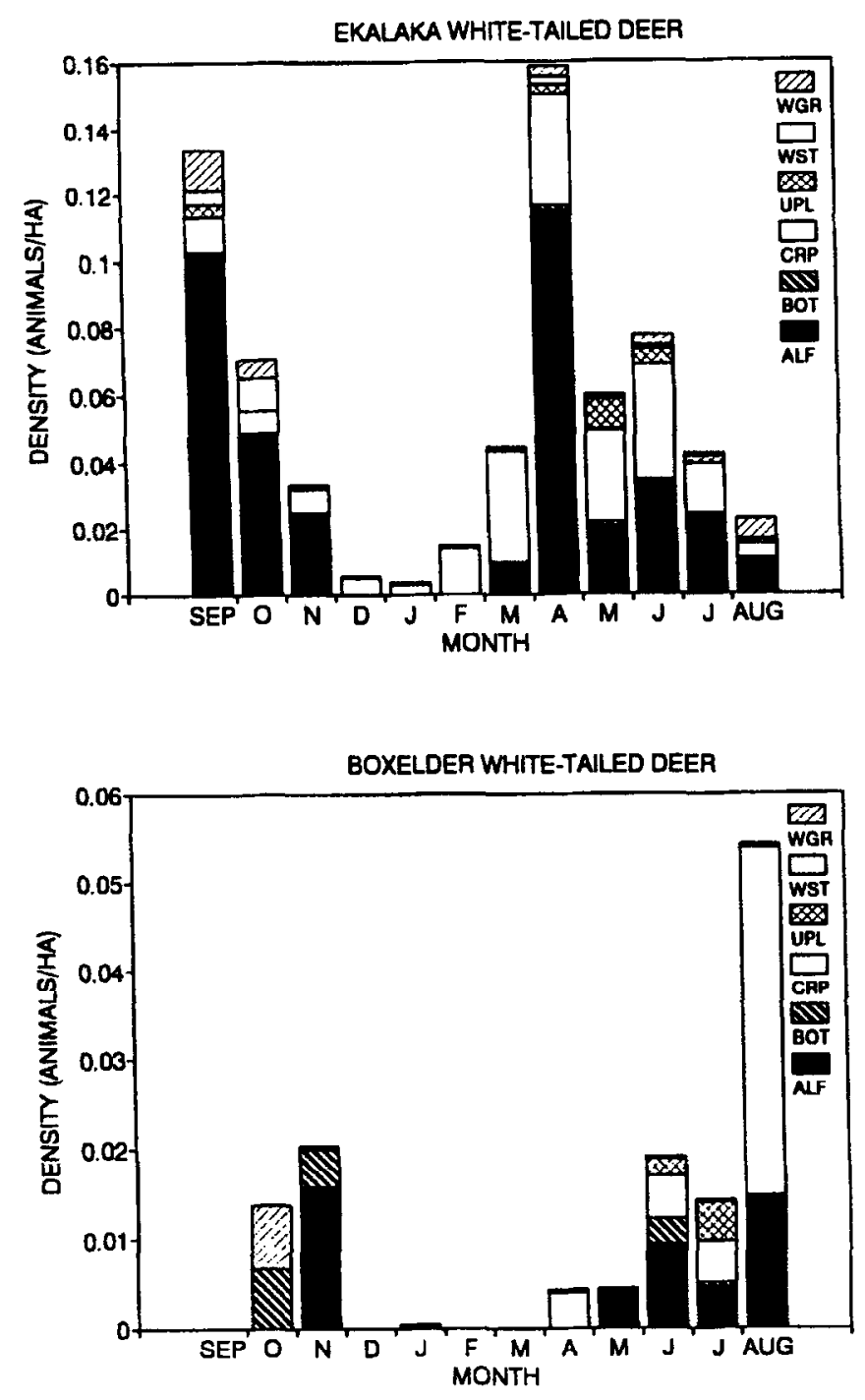

Fig. 2. Average white-tailed deer densities on alfalfa (ALF), bottom rangeland (BOT), Conservation Reserve Program (CRP), upland rangeland (UPL), wheat stubble (WST), and growing wheat (WGR) observation sites in the Ekalaka and Box Elder study areas from September 1992 to August 1993.

ed to be seen in bottom land pastures more than in upland pastures probably in response to shade, water, and/or forage in riparian areas. In winter and early spring, many ranchers allowed their cattle to graze on alfalfa and wheat fields. There were no significant differences (Kruskall-Wallace tests, $P=0.12$ to 0.40 ) in number of domestic sheep observed in upland and lowland sites in any season. Most ranchers did not graze sheep on alfalfa or wheat fields. Horses were observed on only one observation site and were not included in the analysis.

Correlations between ungulate numbers and cattle were generally poor. White-tailed deer numbers were negatively correlated with cattle presence in spring $\left(R_{\mathrm{s}}=-0.386, P<0.01\right)$, and sum$\operatorname{mer}\left(\mathrm{R}_{\mathrm{s}}=-0.369, P<0.01\right)$. There were no significant $(P<0.05)$ associations evident between sheep and wild ungulates.

\section{Discussion}

Use of Agricultural Lands

Upland and bottom land range were the most abundant of the agricultural cover categories we sampled and the most common agricultural land use types in eastern Montana (Montana Agricultural Statistics Service 1993). Wild ungulates generally used these types in less than expected proportions. This low relative level of use does not imply that native range is unimportant to wild ungulates in Montana (Pyrah 1987, Wood et al. 1989). It merely indicates that rangeland was so abundant that it was not limiting at current population levels. During 1992-93, forage

Table 3. Seasonal Spearman rank (Rs) correlation coefificients for wild ungulates and landscape variables in all seasons.

\begin{tabular}{|c|c|c|c|c|c|c|c|}
\hline & & \multicolumn{2}{|c|}{ MUL" } & \multicolumn{2}{|c|}{ WTD } & \multicolumn{2}{|c|}{ ANT } \\
\hline & & $\mathbf{R s}^{\mathrm{b}}$ & $\mathbf{P}$ & Rs & $\mathbf{P}$ & Rs & $\mathbf{P}$ \\
\hline \multicolumn{8}{|c|}{ Fall } \\
\hline \multirow[t]{9}{*}{ Dist to } & ALF & -0.12 & 0.45 & 0.10 & 0.51 & -0.01 & 0.94 \\
\hline & CRP & -0.17 & 0.27 & -0.19 & 0.21 & 0.04 & 0.82 \\
\hline & WHT & 0.09 & 0.57 & 0.02 & 0.90 & 0.12 & 0.46 \\
\hline & PCK & -0.16 & 0.23 & 0.10 & 0.45 & -0.20 & 0.15 \\
\hline & ICK & -0.22 & 0.10 & -0.08 & 0.54 & 0.18 & 0.19 \\
\hline & $\mathrm{COV}$ & -0.18 & 0.19 & 0.04 & 0.78 & 0.05 & 0.72 \\
\hline & FOR & -0.08 & 0.58 & -0.20 & 0.15 & 0.14 & 0.31 \\
\hline & HMSD & -0.27 & 0.05 & -0.03 & 0.82 & -0.01 & 0.97 \\
\hline & SLOPE & -0.02 & 0.88 & -0.35 & 0.01 & 0.01 & 0.93 \\
\hline \multicolumn{8}{|c|}{ Winter } \\
\hline \multirow[t]{9}{*}{ Dist to } & ALF & -0.07 & 0.67 & 0.13 & 0.40 & 0.28 & 0.07 \\
\hline & CRP & -0.30 & 0.04 & 0.09 & 0.54 & 0.01 & 0.94 \\
\hline & WHT & 0.15 & 0.36 & 0.06 & 0.74 & 0.18 & 0.26 \\
\hline & PCK & -0.19 & 0.17 & 0.01 & 0.96 & 0.06 & 0.68 \\
\hline & ICK & 0.16 & 0.24 & 0.18 & 0.18 & 0.27 & 0.05 \\
\hline & Cov & -0.20 & 0.14 & -0.06 & 0.67 & 0.08 & 0.58 \\
\hline & FOR & 0.26 & 0.05 & 0.11 & 0.44 & 0.26 & 0.06 \\
\hline & HMSD & 0.05 & 0.72 & 0.18 & 0.19 & 0.09 & 0.50 \\
\hline & SLOPE & 0.12 & 0.38 & -0.13 & 0.34 & 0.16 & 0.26 \\
\hline \multicolumn{8}{|c|}{ Spring } \\
\hline \multirow[t]{10}{*}{ Dist to } & ALF & -0.18 & 0.25 & 0.12 & 0.43 & 0.00 & 0.98 \\
\hline & CRP & -0.31 & 0.03 & -0.40 & 0.01 & -0.02 & 0.91 \\
\hline & WHT & 0.02 & 0.90 & -0.05 & 0.77 & 0.03 & 0.85 \\
\hline & PCK & -0.20 & 0.14 & 0.21 & 0.11 & 0.08 & 0.57 \\
\hline & ICK & 0.07 & 0.59 & -0.19 & 0.16 & 0.11 & 0.41 \\
\hline & COV & -0.12 & 0.38 & -0.13 & 0.33 & 0.11 & 0.43 \\
\hline & FOR & 0.14 & 0.31 & -0.33 & 0.01 & 0.03 & 0.02 \\
\hline & HMSD & -0.24 & 0.08 & 0.12 & 0.40 & 0.30 & 0.03 \\
\hline & SLOPE & -0.04 & 0.78 & -0.28 & 0.04 & -0.12 & 0.40 \\
\hline & \multicolumn{7}{|c|}{ Summer } \\
\hline \multirow[t]{9}{*}{ Dist to } & ALF & -0.10 & 0.53 & 0.06 & 0.68 & 0.10 & 0.51 \\
\hline & CRP & -0.14 & 0.37 & -0.17 & 0.27 & -0.02 & 0.91 \\
\hline & WHT & -0.07 & 0.69 & -0.04 & 0.80 & -0.07 & 0.69 \\
\hline & PCK & -0.23 & 0.10 & 0.14 & 0.30 & 0.05 & 0.70 \\
\hline & ICK & 0.04 & 0.75 & -0.26 & 0.06 & 0.18 & 0.18 \\
\hline & COV & -0.07 & 0.64 & -0.04 & 0.76 & 0.22 & 0.11 \\
\hline & FOR & 0.30 & 0.03 & -0.06 & 0.65 & 0.27 & 0.04 \\
\hline & HMSD & -0.26 & 0.06 & -0.11 & 0.43 & 0.34 & 0.01 \\
\hline & SLOPE & 0.15 & 0.28 & -0.17 & 0.21 & 0.12 & 0.39 \\
\hline
\end{tabular}

${ }^{\mathrm{a}} \mathrm{MUL}=$ mule deer, $\mathrm{WTD}=$ white-tailed deer; $\mathrm{ANT}=$ antelope.

${ }^{b} \mathrm{RS}=$ spearman rank correlation coefficient; $\mathrm{P}=\mathrm{p}$-value.

'Dist = distance from observation site to nearest: $A L F=$ alfalfa; $C R P=$ conservation reserve program land; WHT = wheat; PCK = perennial creek; ICK = intermittent creek; COV = hiding cover, FOR = forest; HMSD = occupied homestead. SLOPE = land slope (\%). 

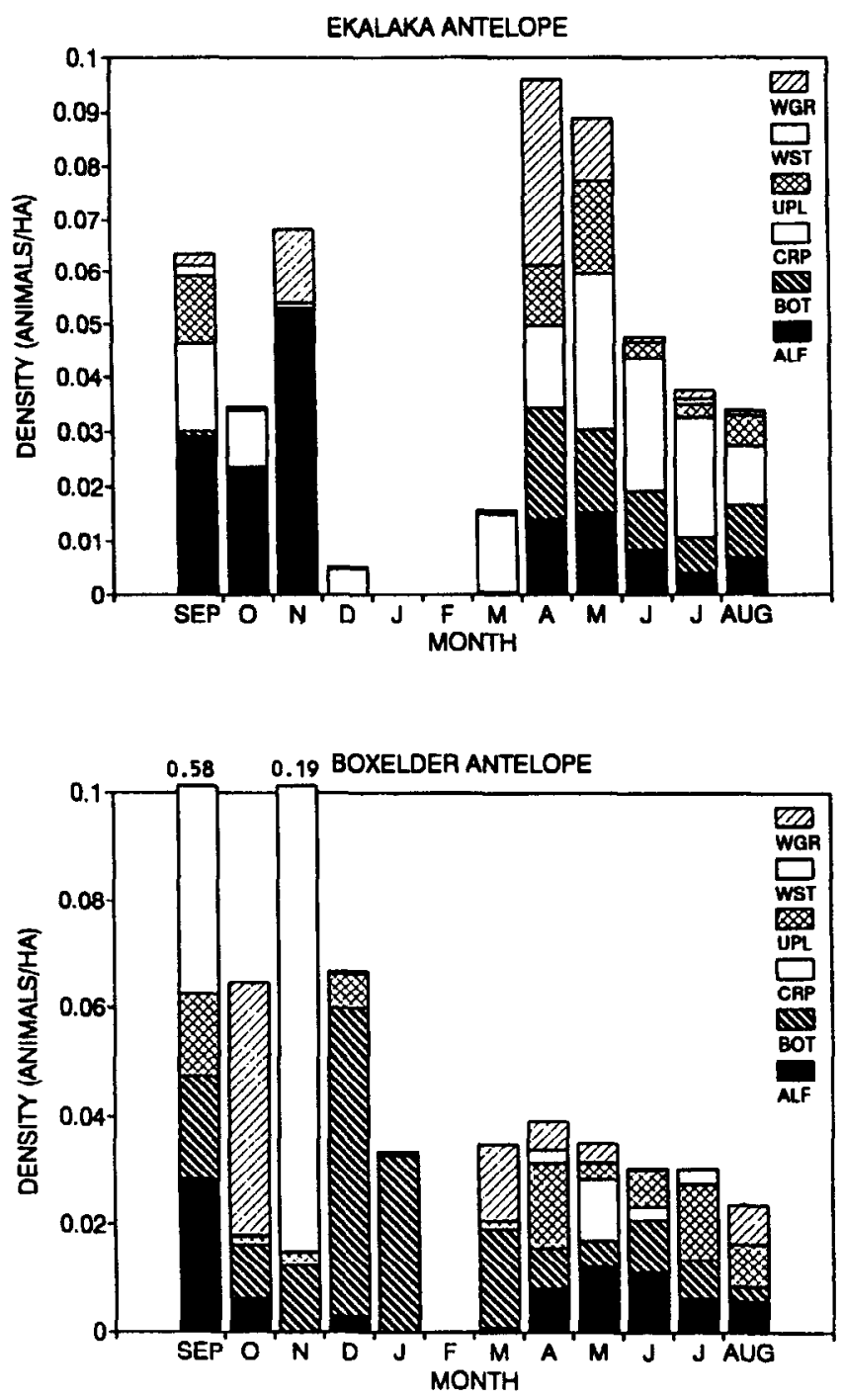

Fig. 3. Average antelope densities on alfalfa (ALF), bottom rangeland (BOT), Conservation Reserve Program (CRP), upland rangeland (UPL), wheat stubble (WST), and growing wheat (WGR) observation sites in the Ekalaka and Box Elder study areas from September 1992 to August 1993.

consumption by wild ungulates at most range sites in our study was unlikely to be measurable using standard range measurement techniques. The maximum average monthly density ( 0.1 animals/ha) of wild ungulates (deer plus antelope) occurred in upland range sites during February on the Box Elder route. If AUM equivalency were to be calculated very liberally (i.e. assume the average wild ungulate is equal to 1 domestic sheep and make no allowances for dietary differences), the stocking rate of wild ungulates on native range observation sites (average AUM in each month summed over all months) would have been 0.03 and $0.07 \mathrm{AUM} / \mathrm{ha} / \mathrm{year}$ in the Ekalaka and Box Elder areas, respectively.

The CRP lands were used in greater than expected proportion in more seasonal tests than any other type. One or more ungulate species favored this type in every season, and all 3 species on the Ekalaka route used it preferentially in winter, spring, and fall. The highest monthly average density was 0.4 animals/ha during
April on the Box Elder route. Even though CRP sites were favored, the annual AUM equivalency (calculated as we did for range sites) was low in 1992-93, 0.1 and $0.4 \mathrm{AUM} / \mathrm{ha} / \mathrm{year}$ for the Ekalaka and Box Elder areas, respectively.

Gould and Jenkins (1993) noted the importance of CRP to white-tailed deer in South Dakota. Thomas and Irby (1991) demonstrated that perennial grass plantings similar to CRP mixes were used heavily by mule deer in southeastern Idaho. Umess et al. (1983) demonstrated that crested wheatgrass (A. desertoreum), a major component in CRP plantings, was an important winter forage for mule deer in Utah. They noted that crested wheatgrass often produced greater fall regrowth and earlier spring growth than native grasses. This favorably affected the nutritional plane of wintering mule deer because the green crested wheatgrass had relatively high protein levels compared to dormant native grass and browse species.

Wild ungulates are apparently attracted to CRP in eastern Montana for its forage and cover value. The CRP sites we observed had not been grazed for several years and had dense stands of exotic wheatgrasses. The stands were taller, denser, and had greater standing and ground litter cover than native range sites we measured (Selting 1994). The relatively dense vegetation in CRP trapped snow and retained moisture better than native range sites.

Because the CRP lands were neither grazed nor mowed, they provided better cover than native range or hay fields. Parker and Gillingham (1990) demonstrated that the effects of vegetative structure on temperature, wind speed, and solar radiation benefited wintering mule deer. The CRP lands were evidently comparable in quality for hiding fawns, hiding adults, wind protection in winter, and shade in summer to the topographic features, riparian tree stands, and shrubs ungulates routinely select in the prairies of eastern Montana (Wood et al. 1989, Olenicki 1993).

Alfalfa fields were the most heavily used land type on the Ekalaka route and ranked second on the Box Elder route. Whitetailed deer were more closely tied to this land use type than antelope or mule deer, but all 3 species selected alfalfa in at least 1 season. The greatest density of ungulates using alfalfa was $0.4 / \mathrm{ha}$ in September on the Box Elder route, but the calculated AUM value for 1992-93 was only $0.2 \mathrm{AUM} / \mathrm{ha} / \mathrm{yr}$ for both routes.

In eastern Montana, increased use of alfalfa fields during autumn by deer is well documented (Egan 1957, Wood et al. 1989, Griffiths 1990). Most alfalfa fields remain green longer than native forages due to their location in bottom land areas

Table 4. Regression Coefficient of determination (R2) (P-values in parentheses) from multiple regression models for mule deer, white-tailed deer, and antelope using ungulate density as the dependent variable and landscape variables as independent variables.

\begin{tabular}{lccc}
\hline Season & Mule deer & $\begin{array}{c}\text { White-tailed } \\
\text { deer }\end{array}$ & Antelope \\
\hline Fall & 0.30 & 0.23 & 0.09 \\
& $(0.08)$ & $(0.30)$ & $(0.25)$ \\
Winter & 0.18 & 0.50 & 0.17 \\
& $(0.75)$ & $(<0.01)$ & $(0.85)$ \\
Spring & 0.17 & 0.24 & 0.17 \\
& $(0.90)$ & $(0.30)$ & $(0.83)$ \\
Summer & 0.19 & 0.20 & 0.15 \\
& $(0.61)$ & $(0.51)$ & $(0.91)$ \\
\hline
\end{tabular}


where they benefit from runoff and subirrigation. Olenicki (1993) documented the decrease in forage succulence on uplands adjacent to alfalfa bottoms on Box Elder Creek as summer progressed.

The critical time for financial loss of growing alfalfa is between green-up and harvest. Austin and Urness (1993) developed a model to estimate losses to deer based on the average night counts of deer on fields. When we applied this model to dusk and night counts, the average total losses we calculated for April through August were generally low $(14.2 \mathrm{~kg} / \mathrm{ha})$. The greatest loss we estimated for an individual field over the 5-month growing season was $35.1 \mathrm{~kg} / \mathrm{ha} / \mathrm{mo}$. Alfalfa consumption in the summer of 1993 was probably lower than average even though ungulate densities were near average. High rainfall, distribution of rain throughout summer, and abundant sweet clover probably delayed and reduced alfalfa use relative to an average or dry summer. The common practice of foregoing a second cut and saving alfalfa for seed harvest during dry years tends to increase depredation problems above that associated with foliage losses.

Wheat stubble was used less than expected in more tests than any other land use type. Sightings of large antelope herds in a few fields along the Box Elder route in September produced the highest monthly average density, 0.6 animals/ha. Annual AUM estimates were $<0.1$ and $0.2 \mathrm{AUM} / \mathrm{ha} /$ year for the Ekalaka and Box Elder areas, respectively. Ungulate densities in growing wheat were even lower. Annual AUM estimates were $<0.1$ AUM/ha/year for both study areas.

The potential for reductions in wheat yield due to ungulate use of fields was low. Wheat is generally not vulnerable to yield reduction from grazing until the growing point emerges from the ground (Dunphy et al. 1982). In Carter County, wheat growing point emergence occurs around May 15 at the earliest (Bauer et al. 1992, Schafer et al. 1985). Ungulate use of growing wheat peaked in April at $0.04 \mathrm{animals} / \mathrm{ha}$ but declined to $<0.01$ animal/ha by May.

\section{Predicting Use Patterns}

The associations between landscape variables and use of specific sites by ungulates followed expected patterns but were generally weak. Deer tended to be more abundant at sites close to preferred foraging areas (CRP and alfalfa fields) and near topography or vegetation that provided cover (stream channels, forests, and shrublands). White-tailed deer were more closely associated with flat, riparian areas than mule deer. Antelope were associated with flat, open terrain. Combinations of these factors in multivariate models did not improve site-specific predictability. The vegetation characteristics and livestock numbers at individual sites also showed little promise of producing tight predictive models. The associations we found were consistent with those outlined in earlier studies in the area (Egan 1957, Campbell 1970, Freeman 1971, Griffiths 1990, Olenicki 1993).

Our failure to discover a strong correlation between numbers of animals at specific sites and habitat factors was not due to selection of inappropriate independent variables or to poor sampling design. The habitat features measured in this study are widely recognized as important to deer and antelope in dry northern prairies (Severson 1981, Pyrah 1987, Kitchen and O'Gara 1982, Petersen 1984, Wood et al. 1989). Because we were able to sample large animals in open terrain and were able to sample individual sites frequently and systematically, we obtained much better estimates of use patterns at individual sites than most landscape level studies. We did not have large sample sizes of sites, but we were able to use reasonably robust statistical models to search for landscape associations. The loose associations between animal numbers and habitat features we observed accurately reflect reality in southeastern Montana.

Deer and antelope are large, long lived animals who occupy large ranges and depend heavily on learning to form habitat use patterns within those ranges. They can and do change use patterns in response to favorable and unfavorable changes in resources and disturbance. Given these conditions, the past history of each site would have to be reduced to a mathematical term to produce a valid predictive model, and each site would likely have a unique value for this term. Even if terms were developed, the variability in use of sites may actually be small when compared to variability in attitudes towards wild ungulates among individual farmers and ranchers (Irby et al. unpublished data).

This is not encouraging for managers interested in working from a computer terminal. It does suggest a strategy for managing wild ungulates on private agricultural land in eastern Montana: managers should concentrate on working with individual landowners rather than searching for global solutions. Research projects should be used to identify conditions where problems might develop and to determine the efficacy of different approaches to resolving problems, but landowners and agency personnel should plan on discussing options for resolving problems on a site-by-site basis.

\section{Literature Cited}

Adkins, RJ. 1991. An analysis of game damage and game damage complaints in Montana. M.S. Thesis, Montana State Univ. Bozeman, Mont. Austin, D.D. and P.J. Urness. 1993. Evaluating production losses from mule deer depredation in alfalfa fields. Wildl. Soc. Bull. 21:397-401.

Bauer, A., A.B. Frank, and A.L. Black. 1992. A crop calendar for spring wheat and for spring barley. North Dakota Farm Res. 49:21-25.

Campbell, R.B. 1970. Pronghorn, sheep, and cattle relationships in Carter County, Montana. M.S. Thesis, Montana State Univ., Bozeman, Mont.

Carter County Conservation District. 1976. Long range program. U.S.D.A. Soil Conservation Service.

Conover, M.R. 1994. Perceptions of grass-roots leaders of the agricultural community about wildlife damage on their farms and ranches. Wildl. Soc. Bull. 22:94-100.

Conover, M.R. and D.J. Decker. 1991. Wildlife damage to crops: perceptions of agricultural and wildlife professionals in 1957 and 1987. Wildl. Soc. Bull. 19:46-52.

Conover, WJ. 1980. Practical nonparametric statistics. John Wiley and Sons, N.Y.

Dunphy, D.J., M.E. McDaniel, and E.C. Holt. 1982. Effect of forage utilization on wheat grain yield. Crop Sci. 22:106-108.

Egan, J.E. 1957. Some relationships between mule deer and alfalfa production in Powder River County, Montana. M.S. Thesis, Montana State College, Bozeman, Mont.

Freeman, J.S. 1971. Pronghorn range use and relation to livestock in southeastern Montana. M.S. Thesis, Montana State Univ., Bozeman, Mont.

Gould, J.H. and K.J. Jenkins. 1993. Seasonal use of conservation reserve program lands by white-tailed deer in east-central South Dakota. Wildl. Soc. Bull. 21:250-25.

Griffiths, D.E. 1990. Green vegetation and fecal protein relationships in two southeastern Montana deer populations. M.S. Thesis, Montana State Univ., Bozeman, Mont.

Irby, L.R., W.E. Zidack, J.B. Johnson, and J. Saltiel. 1996. Economic damage to forage crops by native ungulates as perceived by farmers and ranchers in Montana. J. Range. Manage. 49:375-380. 
Kitchen, D.W. and B.W. O'Gara. 1982. Pronghorn, p. 960-971. In: J.A. Chapman and G.A. Feldhamer (ed.), Wild mammals of North America: biology, management, and economics. Johns Hopkins Univ. Press, Baltimore, Md.

Lacey, J.R., K. Jamtgaard, L. Riggle, and T. Hayes. 1993. Impacts of big game on private land in southwestern Montana: landowner perceptions. J. Range Manage. 46:31-37.

Matschke, G.H., D.S. deCalesta, and J.D. Harder. 1984. Crop damage and control. p. 647-654. In: L.K. Halls (ed.), White-tailed deer: ecology and management. Stackpole Books, Harrisburg, Penn.

Montana Agricultural Statistics Service. 1993. Montana agricultural statistics 1991-1992, vol. 30. Montana Dept. Agr., Helena, Mont.

Neter J., W. Wasserman, and G.A. Whitmore. 1993. Applied statistics. Allyn and Bacon, Boston, Mass.

Neu, C.W., R. Byers, and J.M. Peek. 1974. A technique for analysis of utilization-availability data. J. Wildl. Manage. 38:541-545.

NOAA. 1993. Climatological data, Montana. U.S. Dept. of Commerce, Asheville, N.C.

Olenicki, T.J. 1993. Seasonal use of fecal nitrogen and forage succulence to assess condition and movements of two southeastern Montana mule deer populations. M.S. Thesis, Montana State Univ., Bozeman, Mont.

Parker, K.L. and M.P. Gillingham. 1990. Estimates of critical thermal environments for mule deer. J. Range Manage. 43:73-80.

Petersen, L.E. 1984. Northern Plains. p. 441-448. In: L.K. Halls (ed.), White-tailed deer: ecology and management. Stackpole Books, Harrisburg, Penn.
Pyrah, D.B. 1987. American pronghorn antelope in the Yellow Water Triangle, Montana. Montana Dept. Fish, Wildl. and Parks Tech. Bull.

Schafer, W., J. Bauder, and A. Jones. 1985. The Montana small grain guide. Montana Coop. Ext. Serv. Bull. No. 364.

Selting, J.P. 1994. Seasonal use of agricultural lands by mule deer, white-tailed deer, and pronghom antelope in Carter County, Montana. M.S. Thesis, Montana State Univ., Bozeman, Mont.

Severson, K.E. 1981. Plains habitats. P. 459-485 In: O.C. Wallmo (ed.), Mule and black-tailed deer of North America. Univ. of Nebraska Press, Lincoln, Neb.

Tebaldi, A. 1982. Effects of deer use on winter wheat and alfalfa production. Wyoming Game and Fish Dept. Fed. Aid Fish Wildl. Restor. Final Rep. FW-3-R-26, Cheyenne, Wyo.

Thomas, T.R. and L.R. Irby. 1991. Winter habitat use by mule deer with access to wheat fields and planted forb-grassland. Wildl. Soc. Bull. 19:155-162.

Urness, P.J., D.D. Austin, and L.C. Fierro. 1983. Nutritional value of crested wheatgrass for wintering mule deer. J. Range Manage. 36:225-226.

Wood, A.K., R.J. Mackie, and K.L. Hamlin. 1989. Ecology of sympatric mule and white-tailed deer populations in a prairie environment. Tech. Bull., Mont. Dept. of Fish, Wildl. and Parks, Helena, Mont.

Wywialowski, A.P. 1994. Agricultural producers' perceptions of wildlife-caused losses. Wildl. Soc. Bull. 22:370-382.

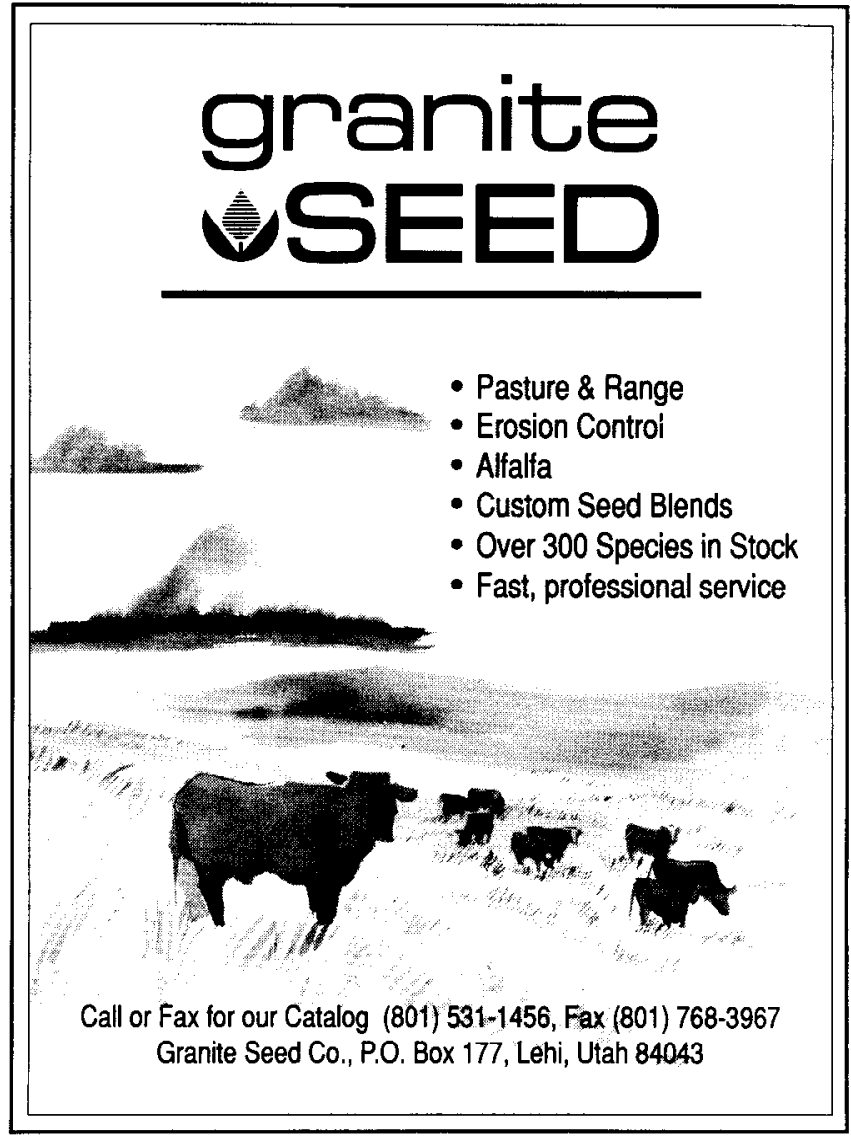

